\title{
PERBANDINGAN PENGGUNAAN MODEL PEMBELAJARAN KONVENSIONAL DAN MODEL PEMBELAJARAN PROJECT BASED LEARNING TERHADAP HASIL BELAJAR GAMBAR KONSTRUKSI BANGUNAN SISWA KELAS XI TGB A SMKN 2 SURAKARTA TAHUN AJARAN 2016/2017
}

\author{
Arif Mahdiyanto $^{1}$, Eko Supri Murtiono², A.G. Tamrin ${ }^{3}$ \\ Email : amahdiyanto@gmail.com
}

\begin{abstract}
Abstrak : Penelitian ini bertujuan untuk (1) Mengetahui ada atau tidak perbedaan hasil belajar ranah kognitif antara mengggunakan model pembelajaran konvensional dengan model pembelajaran Project Based Learning; (2) Mengetahui ada atau tidak perbedaan hasil belajar ranah afektif antara mengggunakan model pembelajaran konvensional dengan model pembelajaran Project Based Learning; (3) Mengetahui ada atau tidak perbedaan hasil belajar ranah psikomotorik antara mengggunakan model pembelajaran konvensional dengan model pembelajaran Project Based Learning pada mata pelajaran Gambar Konstruksi Bangunan kelas XI TGB A SMK N 2 Surakarta. Penelitian ini termasuk penelitian eksperimen yang dilaksanakan di kelas XI TGB A. Teknik pengambilan sampel digunakan nonprobability sampling dengan metode purposive sampling. Pengumpulan data dilaksanakan dengan tes dalam bentuk pilihan ganda untuk data hasil belajar siswa pada ranah penilaian kognitif dan observasi untuk data hasil belajar siswa pada ranah afektif dan psikomotorik. Analisa data menggunakan uji wilcoxcon dengan taraf signifikansi 0,05. Hasil penelitian adalah sebagai berikut : Pertama, ada perbedaan hasil belajar ranah kognitif antara menggunakan model pembelajaran Konvensional dan model pembelajaran Project Based Learning $(0.000<0,05)$. Kedua, tidak ada perbedaan hasil belajar ranah afektif antara menggunakan model pembelajaran Konvensional dan model pembelajaran Project Based Learning $(0.221>0.05)$. Ketiga, tidak ada perbedaan hasil belajar ranah afektif antara menggunakan model pembelajaran Konvensional dan model pembelajaran Project Based Learning (0.497 > 0.05).
\end{abstract}

Kata kunci : Konvensional, Project Based Learning, hasil belajar.

\footnotetext{
${ }^{1}$ Mahasiswa Program Studi Pendidikan Teknik Bangunan FKIP UNS

2 Pengajar Program Studi Pendidikan Teknik Bangunan FKIP UNS

3 Pengajar Program Studi Pendidikan Teknik Bangunan FKIP UNS
} 


\title{
PERBANDINGAN PENGGUNAAN MODEL PEMBELAJARAN KONVENSIONAL DAN MODEL PEMBELAJARAN PROJECT BASED LEARNING TERHADAP HASIL BELAJAR GAMBAR KONSTRUKSI BANGUNAN SISWA KELAS XI TGB A SMKN 2 SURAKARTA TAHUN AJARAN 2016/2017
}

\author{
Arif Mahdiyanto $^{1}$, Eko Supri Murtiono², A.G. Tamrin ${ }^{3}$ \\ Email : amahdiyanto@gmail.com
}

\begin{abstract}
This research aims to (1) determine whether or not differences cognitive domain between using Conventional learning model with Project Based Learning model; (2) determine whether or not differences affective domain between using Conventional learning model with Project Based Learning model; (3) determine whether or not differences psychomotor domain between using Conventional learning model with Project Based Learning model on result of learning subject Drawing Building Construction in class XI TGB A SMKN 2 Surakarta School Year 2016/2017. This research includes experiment research conducted in class XI TGB A. The sampling technique used nonprobability sampling with purposive sampling method. The collection of data carried out by multiple choice test for data of student learning result in the cognitive and observation for data of student learning result in the affective and psychomotor. The data analysis using wilcoxcon test with significance level on 0.05. The result of this research are as follows :First, there are differences on learning result between cognitive domain using Conventional learning model and Project Based Learning model $(0.000<0,05)$. Second, there are not differences on learning result between affective domain using Conventional learning model and Project Based Learning model (0.221 > 0.05). Third, there are not differences on learning result between psychomotor domain using Conventional learning model and Project Based Learning model (0.497 > 0.05).
\end{abstract}

Keywords : Conventional, Project Based Learning, learning result

\footnotetext{
${ }^{1}$ Mahasiswa Program Studi Pendidikan Teknik Bangunan FKIP UNS

2 Pengajar Program Studi Pendidikan Teknik Bangunan FKIP UNS

3 Pengajar Program Studi Pendidikan Teknik Bangunan FKIP UNS
} 


\section{PENDAHULUAN}

Dewasa ini pendidikan dituntut untuk lebih bisa berkembang guna mempersiapkan sumber daya manusia yang berkualitas dan berdaya saing tinggi di kancah ketenaga-kerjaan baik di negara sendiri maupun skala internasional. Guna menciptakan sumber daya manusia yang profesional di bidangnya memerlukan proses pembelajaran yang terstruktur dan efisien di dalam pelaksanaannya. Keberhasilan proses pembelajaran sebagai proses pendidikan di suatu sekolah dipengaruhi oleh banyak faktor. Faktor-faktor yang dimaksud misalnya guru, siswa, kurikulum, lingkungan sosial, dan lain-lain. Berdasarkan hal tersebut, guru dituntut untuk dapat memilih model pembelajaran yang tepat sehingga materi dapat tersampaikan dan mudah untuk dipahami oleh siswa serta siswa dapat turut berperan aktif dalam proses pembelajaran tersebut. Pendekatan dan model pembelajaran harus disusun berdasarkan karakteristik siswa dan materi yang akan disampaikan. Dikarenakan tidak semua model pembelajaran cocok dengan materi yang akan guru sampaikan kepada para siswanya. Selain itu, pendekatan dan model pembelajaran yang digunakan harus mampu menarik minat belajar siswa, sehingga siswa dapat merasa nyaman dalam kegiatan pembelajaran dan dalam kondisi tersebut diharapkan didapatkan hasil belajar yang maksimal. Dengan kata lain, pendekatan dan model pembelajaran yang tepat menghasilkan hasil belajar yang maksimal.

Berdasarkan pengamatan peneliti selama melaksanakan Praktik Pengalaman Lapangan (PPL) dalam kurun waktu bulan September 2016 Desember 2016 pembelajaran Gambar Konstruksi Bangunan di kelas XI Teknik Gambar Bangunan SMK N 2 Surakarta masih menggunakan model terpusat pada guru atau konvensional sehingga dirasa kurang variatif dan kurang menuntut partisipasi aktif dari siswa.

Menurut Winkel (1991: 178) Pembelajaran konvensional disebut dengan pembelajaran dengan prosedur didaktik. Kegiatan-kegiatan yang dilakukan oleh guru selama proses pembelajaran berlangsung, agar siswa dapat mencapai tujuan dengan efektif dapat dikelompokkan dalam tiga pola, 
yaitu pola narasi, pola perundingan bersama, dan pola pemberian tugas. Model pembelajaran ini efektif apabila digunakan dalam konteks menyampaikan sebuah informasi yang bersifat teoritis atau sebuah pengertian. Namun dirasa kurang efektif apabila digunakan dalam mengolah keterampilan dan membentuk karakter siswa.

Selain model pembelajaran konvensional yang berbasis teacher centered ada alternatif pilihan model pembelajaran berbasis student centered yang dirasa lebih cocok untuk mengolah keterampilan siswa, dimana siswa dituntut untuk bisa mengembangkan keterampilan memecahkan masalah yang ada, yaitu model pembelajaran Project Based Learning. Model Pembelajaran Project Based Learning adalah sebuah model pembelajaran inovatif dan lebih menekankan pada pembelajaran kontekstual melalui kegiatan yang kompleks. Pembelajaran belajar yang lebih menarik dan bermakna bagi siswa (Wena, 2011 : 145).

Berdasarkan latar belakang tersebut penelitian ini bertujuan untuk mengetahui ada atau tidak perbedaan hasil belajar ranah kognitif, afektif dan psikomotorik antara mengggunakan model pembelajaran konvensional dengan model pembelajaran Project Based Learning pada mata pelajaran Gambar Konstruksi Bangunan kelas XI TGB A SMK N 2 Surakarta.

Menurut Oemar Hamalik (2003: 154) "belajar adalah perubahan tingkah laku yang relatif menetap berkat latihan dan pengalaman". Untuk itu belajar membawa sesuatu perubahan pada individu yang belajar. Perubahan itu tidak hanya mengenai jumlah pengetahuan melainkan juga dalam bentuk kecakapan kebiasaan, sikap, pengertian, penghargaan, minat, penyesuaian diri atau mengenai segala aspek pribadi seseorang.

Menurut Tabrani Rusyan, Atang Kusdinar dan Zainal Arifin (1989: 62-63), ada empat faktor yang mempengaruhi proses belajar yaitu:

a) Bahan yang dipelajari

b) Lingkungan

c) Instrumen dan

d) Kondisi individu.

Model pembelajaran merupakan kerangka konseptual berupa pola prosedur sistematik yang 
dikembangkan berdasarkan teori dan digunakan dalam mengorganisasikan proses belajar mengajar untuk mencapai tujuan belajar. (Sani, 2013 : 89). Menurut Djamarah (1996), metode pembelajaran konvensional adalah metode pembelajaran tradisional atau disebut juga dengan metode ceramah, karena sejak dulu metode ini telah dipergunakan sebagai alat komunikasi lisan antara guru dengan anak didik dalam proses belajar dan pembelajaran. Project Based Learning adalah suatu pengajaran yang mencoba mengaitkan antara teknologi dengan masalah kehidupan sehari-hari yang akrab dengan siswa, atau dengan suatu proyek sekolah. Warsono \& Harianto (2012: 153).

Mata pelajaran Gambar Konstruksi Bangunan tergolong dalam mata pelajaran kelompok peminatan (C). Dimana pada mata pelajaran ini lebih menonjolkan aspek keterampilannya namun tidak melupakan aspek pengetahuannya. Diharapkan proses pembelajaran pada mata pelajaran Gambar Konstruksi Bangunan melalui model pembelajaran yang tepat dapat menghasilkan hasil belajar yang maksimal. Untuk melihat sejauh mana taraf keberhasilan mengajar guru dan belajarnya peserta didik secara tepat (valid) dan dapat dipercaya (reliable), diperlukan suatu informasi tentang indikator-indikator perubahan tingkah laku dan pribadi peserta. Menurut Bloom dalam Djamaah Sopaah (2000: 104) "mengkategorikan prestasi menjadi 3 ranah yaitu ranah kognitif, ranah afektif, ranah psikomotorik".

Hipotesis dalam penelitian ini yaitu terdapat perbedaan antara hasil belajar ranah kognitif, afektif dan psikomtorik model pembelajaran Konvensional dan model pembelajaran Project Based Learning terhadap prestasi belajar Gambar Konstruksi Bangunan.

\section{METODE PENELITIAN}

Penelitian ini dilaksanakan di SMK N 2 Surakarta yang beralamat di Jalan Adi Sucipto No. 33, Surakarta, Jawa Tengah. Telp. (0271) 714901. Penelitian ini dilaksanakan pada bulan Januari - Agustus 2017. Dalam penelitian ini peneliti menggunakan penelitian eksperimen kuasi (semu). Eksperimen dilaksanakan di satu kelas yaitu kelas XI TGB A dengan 
meninjau model pembelajaran Konvensional yang sebelumnya telah diterapkan dan model pembelajaran Project Based Learning yang merupakan model pembelajaran perlakuan baru yang akan dilaksanakan oleh peneliti. Populasi pada penelitian ini adalah semua peserta didik kelas XI TGB dan XII TGB yang terdapat mata pelajaran Gambar Konstruksi Bangunan. Lebih terperinci yaitu pada kelas XII TGB A, XII TGB B, XI TGB A dan XI TGB B. Populasi dalam penelitian ini termasuk ke dalam jenis populasi terbatas, dikarenakan keseluruhan peserta didik di dalam populasi masih dapat dihitung. Sampel dalam penelitian ini adalah siswa kelas XI TGB A yang berjumlah 32 siswa serta mendapatkan mata pelajaran Gambar Konstruksi Bangunan. Dimana kedua hasil belajar Gambar Konstruksi Bangunan dari dua model pembelajaran yang akan ditinjau oleh peneliti keseluruhannya diterapkan pada sampel (siswa kelas XI TGB A).

Teknik pengambilan sampel menggunakan nonprobability sampling dengan metode purposive sampling. Sesuai dengan tujuan yang ingin dicapai peneliti yaitu mengetahui prestasi belajar siswa dalam mata pelajaran gambar konstruksi bangunan, peneliti mengambil kelas XI TGB A sebagai objek penelitian karena kelas tersebut dirasa mampu mewakili karakteristik populasi yang diinginkan.

Teknik pengumpulan data yang digunakan oleh peneliti meliputi tes, dokumentasi dan observasi. Variabel bebas dalam penelitian ini adalah Model Pembelajaran Project Based Learning dan Model Pembelajaran Konvensional. Variabel terikat dalam penelitian ini adalah hasil belajar siswa pada mata pelajaran Gambar Konstruksi Bangunan. Teknik uji validitas dan reliabilitas instrumen digunakan untuk kesiapan pengambilan data pada eksperimen yang dilakukan peneliti. Uji normalitas dalam penelitian ini menggunakan Shapiro-Wilk, dikarenakan jumlah sampel yang sedikit (kurang atau sama dengan dari 50). Uji analisis data dalam penelitian ini menggunakan uji wilcoxon dikarenakan data tidak berdistribusi normal. 


\section{HASIL PENELITIAN DAN \\ PEMBAHASAN}

\section{Hasil Penelitian}

Pengujian data aspek penilaian kognitif, afektif, dan psikomotorik baik sebelum (konvensional) maupun sesudah perlakuan (project based learning) pada masing-masing kelompok menggunakan uji shapiro wilk karena data tiap kelompok $<50$. Hasilnya data berdistribusi normal jika sig. > 0.05, dan data tidak berdistribusi normal jika sig. $<0.05$.

Tabel 4.1. Hasil Uji Normalitas Data Kognitif, Afektif, dan Psikomotorik pada Data Model Konvensional dan Model PjBL

\begin{tabular}{lccc}
\hline & \multicolumn{3}{c}{$\begin{array}{c}\text { Kolmogorov- } \\
\text { Smirnov }\end{array}$} \\
\cline { 2 - 4 } & Statistic & df & Sig. \\
\hline Kognitif & & & \\
$\begin{array}{l}\text { Model } \\
\text { Konvensional }\end{array}$ & .188 & 32 & .006 \\
$\begin{array}{l}\text { Kognitif } \\
\text { Model PjBL }\end{array}$ & .268 & 32 & .000 \\
$\begin{array}{l}\text { Afektif } \\
\text { Model }\end{array}$ & .191 & 32 & .004 \\
$\begin{array}{l}\text { Konvensional } \\
\text { Afektif }\end{array}$ & & & \\
$\begin{array}{l}\text { Model PjBL } \\
\text { Psikomotorik }\end{array}$ & .192 & 32 & .004 \\
$\begin{array}{l}\text { Model } \\
\text { Konvensional }\end{array}$ & .190 & 32 & .005 \\
$\begin{array}{l}\text { Psikomotorik } \\
\text { Model PjBL }\end{array}$ & .149 & 32 & .069 \\
\hline a. Lilliefors Significance Correction
\end{tabular}

Tabel 4.2.Hasil Uji Normalitas Data Kognitif, Afektif, dan Psikomotorik pada Data Model Konvensional dan Model PjBL

\begin{tabular}{ccc}
\hline & \multicolumn{2}{c}{ Shapiro-Wilk } \\
\cline { 2 - 3 } & Statistic Df Sig. \\
\hline
\end{tabular}

Kognitif

Model $.898 \quad 32 \quad .006$

Konvensional

Kognitif

Model PjBL

$\begin{array}{lll}.732 & 32 & .000\end{array}$

Afektif

Model

$\begin{array}{lll}.927 \quad 32 & .032\end{array}$

Konvensional

Afektif

Model PjBL

$.916 \quad 32 \quad .016$

Psikomotorik

Model

$\begin{array}{lll}.879 & 32 & .002\end{array}$

Konvensional

Psikomotorik

Model PjBL

$\begin{array}{lll}.927 \quad 32 & .032\end{array}$

a. Lilliefors Significance Correction

Sumber: Output SPSS Uji Normalitas

Data

Dari hasil test normalitas menggunakan shapiro wilk diketahui bahwa data tidak berdistribusi normal pada semua aspek penilaian yaitu pada Kognitif Model Konvensional, Kognitif Model PjBL, Afektif Model Konvensional, Afektif Model PjBL, Psikomotorik Model Konvensional, dan Psikomotorik Model PjBL. 
Tabel 4.3. Statistik Deskriptif pada Aspek Penilaian Kognitif

\begin{tabular}{lrr}
\hline & $\begin{array}{c}\text { Kognitif } \\
\text { Model } \\
\text { Konvensional }\end{array}$ & $\begin{array}{c}\text { Kognitif } \\
\text { Model } \\
\text { PjBL }\end{array}$ \\
\hline N Valid $\quad$ Missing & 32 & 32 \\
Mean & 0 & 0 \\
Median & 85.00 & 96.56 \\
Mode & 85.00 & 95.00 \\
Std. & $85^{\text {a }}$ & 100 \\
Deviation & 8.980 & 4.103 \\
Variance & 80.645 & 16.835 \\
Minimum & 60 & 85 \\
Maximum & 95 & 100 \\
Sum & 2720 & 3090 \\
\hline a. Multiple modes & exist. The smallest \\
value is shown & \multicolumn{2}{c}{}
\end{tabular}

Sumber: Output SPSS Statistik Deskriptif

Jika dibandingkan keduanya nilai rata-rata pada model Project Based Learning jauh lebih tinggi dibandingkan model konvensional yaitu 85 dengan 96.56. Nilai tengah lainnya yaitu median juga berbeda jauh pada model konvensional diperoleh nilai median 85 sedangkan pada model Project Based Learning sebesar 95. Berdasarkan penjelasan tersebut dapat disimpulkan bahwa model Project Based Learning meningkatkan nilai kognitif siswa.
Tabel 4.4. Uji Statistik pada Aspek Penilaian Kognitif

\begin{tabular}{lr}
\hline & $\begin{array}{c}\text { Kognitif Model } \\
\text { PjBL - Kognitif } \\
\text { Model } \\
\text { Konvensional }\end{array}$ \\
\hline $\mathrm{Z}$ & $-4.657^{\mathrm{b}}$ \\
$\begin{array}{l}\text { Asymp. Sig. (2- } \\
\text { tailed) }\end{array}$ & .000 \\
\hline b. Based on negative ranks. & \\
Sumber : Output SPSS Uji Wilcoxon & \\
\multicolumn{2}{c}{ Hasil } \\
\end{tabular}
nonparametrik menggunakan wilcoxon diperoleh nilai $\mathrm{Z}$ hitung sebesar -4.657 dengan nilai Asymp. Sig. (2-tailed) sebesar 0.000 . Hal ini berarti bahwa ada perbedaan antara model konvensional dengan model Project Based Learning.

Tabel 4.5. Statistik Deskriptif pada Aspek Penilaian Afektif

\begin{tabular}{lrr}
\hline & \multicolumn{1}{c}{$\begin{array}{c}\text { Afektif } \\
\text { Model } \\
\text { Konvensional }\end{array}$} & $\begin{array}{c}\text { Afektif } \\
\text { Model } \\
\text { PjBL }\end{array}$ \\
\hline \multicolumn{1}{c}{ Valid } & 32 & 32 \\
N Missing & 0 & 0 \\
Mean & 81.2506 & 78.7759 \\
Median & 83.3300 & 79.1700 \\
Mode & 75.00 & 75.00 \\
Std. & 10.58381 & 4.77525 \\
Deviation & 112.017 & 22.803 \\
Variance & 58.33 & 70.83 \\
Minimum & 100.00 & 87.50 \\
Maximum & 2600.02 & 2520.83 \\
Sum & Sutput $\quad$ SPSS & Statistik \\
Sumber : & Outpon &
\end{tabular}


Jika dibandingkan keduanya nilai rata-rata pada model Project Based Learning lebih rendah dibandingkan model konvensional yaitu 81.25 dengan 78.78. Nilai tengah lainnya yaitu median juga berbeda pada model konvensional diperoleh nilai median 83.3 sedangkan pada model Project Based Learning sebesar 79.17. Berdasarkan penjelasan tersebut belum dapat disimpulkan apakah model Project Based Learning meningkatkan nilai afektif siswa.

Tabel 4.6. Uji Statistik pada Aspek Penilaian Afektif

\begin{tabular}{cc}
\hline & Afektif Model \\
& PjBL - Afektif \\
Model \\
\\
Konvensional \\
\hline$Z$ & $-1.224^{c}$
\end{tabular}

Asymp. Sig. (2tailed)

c. Based on positive ranks.

Sumber : Output SPSS Uji Wilcoxon

Hasil pengujian statistik nonparametrik menggunakan wilcoxon diperoleh nilai $Z$ hitung sebesar -1.224 dengan nilai Asymp. Sig. (2-tailed) sebesar 0.221. Hal ini berarti bahwa tidak ada perbedaan antara model konvensional dengan model Project Based Learning pada aspek penilaian afektif.

Tabel 4.7. Statistik Deskriptif pada Aspek Penilaian

Psikomotorik

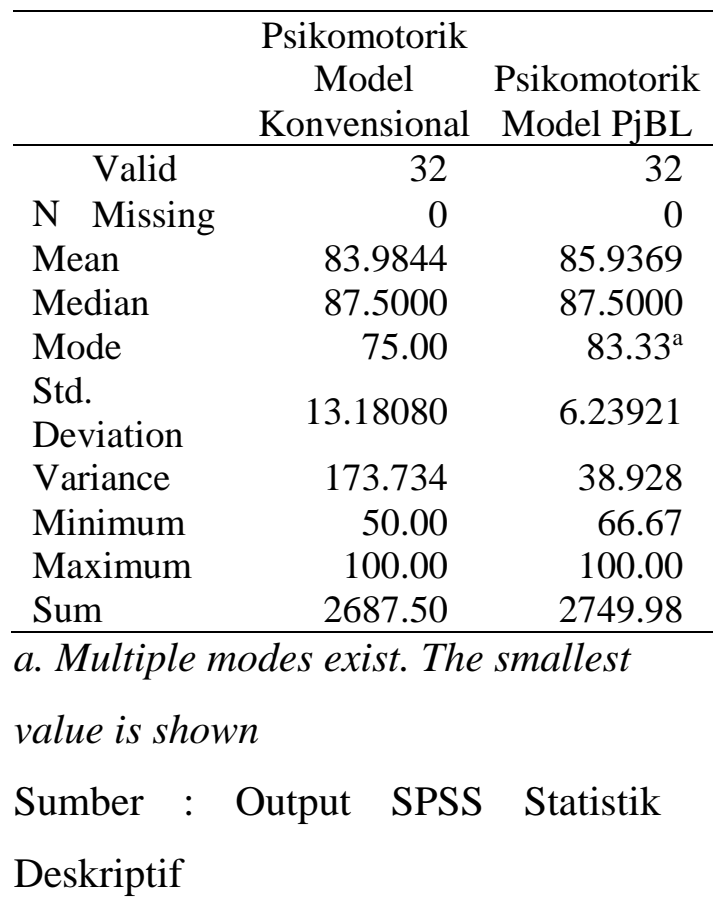

Jika dibandingkan keduanya nilai rata-rata pada model Project Based Learning sedikit lebih tinggi dibandingkan model konvensional yaitu 83.98 dengan 85.94. Nilai tengah lainnya yaitu median ternyata sama pada model konvensional yaitu diperoleh nilai median 87.5 Berdasarkan penjelasan tersebut belum dapat disimpulkan apakah model Project Based Learning meningkatkan 
nilai psikomotorik siswa. Untuk lebih jelasnya digunakan uji statistik. Pengujian secara statistik dilakukan dengan statistik nonparametrik wilcoxon.

Tabel 4.8. Uji Statistik Pada Aspek Penilaian Psikomotorik

\begin{tabular}{rr}
\hline & Psikomotorik Model \\
& PjBL - Psikomotorik \\
& Model Konvensional \\
\hline $\mathrm{Z}$ & $-.679^{\mathrm{b}}$
\end{tabular}

Asymp. Sig.

(2-tailed)

b. Based on negative ranks.

Sumber : Output SPSS Uji Wilcoxon

Hasil pengujian statistik nonparametrik menggunakan wilcoxon diperoleh nilai $\mathrm{Z}$ hitung sebesar -0.679 dengan nilai probabilitas sebesar 0.497. Nilai probabilitas > $0.05(0.497$ $>0.05)$. Hal ini berarti bahwa tidak ada perbedaan antara model konvensional dengan model Project Based Learning pada aspek penilaian psikomotorik.

\section{Pembahasan}

Hasil analisis data penelitian ini mengacu pada rumusan masalah penelitian yang telah diutarakan sebelumnya, yaitu untuk mengetahui ada atau tidak perbedaan antara penggunaan model pembelajaran Konvensional dan model pembelajaran Project Based Learning terhadap hasil belajar Gambar Konstruksi Bangunan siswa kelas XI TGB A SMK Negeri 2 Surakarta tahun ajaran 2016/2017 pada aspek penilitian ranah kognitif, afektif, dan psikomotorik.

Hasil analisa data berdasarkan rumusan masalah yang pertama yaitu terdapat perbedaan antara penggunaan model pembelajaran Konvensional dan model pembelajaran Project Based Learning terhadap hasil belajar Gambar Konstruksi Bangunan siswa kelas XI TGB A SMK Negeri 2 Surakarta tahun ajaran 2016/2017 pada aspek penilitian ranah kognitif. Hasil ini dapat memperkuat teori sebelumnya bahwa ranah kognitif merupakan hasil dari pengembangan kepemilikan pengetahuan dan kemampuan berfikir. Dimana pada model pembelajaran Project Based Learning siswa dituntut untuk dapat berlatih berfikir secara mandiri maupun berkelompok, menggali informasi dan bekerjasama dengan rekannya guna memecahkan masalah yang ada sehingga siswa bisa lebih 
meningkatkan kemampuan berfikirnya serta dapat menambah kepemilikan pengetahuannya. Berbanding terbalik dengan model pembelajaran konvensional yang lebih menuntut guru secara aktif untuk menyampaikan materi dengan sedikit mengikutsertakan keaktifan siswa sehingga siswa cenderung berperan pasif dalam pembelajaran yang dampaknya adalah siswa kurang bisa mengembangkan kemampuan berfikirnya serta kurangnya kepemilikan pengetahuannya.

Hasil analisa data berdasarkan rumusan masalah yang kedua yaitu tidak terdapat perbedaan antara penggunaan model pembelajaran Konvensional dan model pembelajaran Project Based Learning terhadap hasil belajar Gambar Konstruksi Bangunan siswa kelas XI TGB A SMK Negeri 2 Surakarta tahun ajaran 2016/2017 pada aspek penilitian ranah afektif. Hasil ini dapat memperkuat teori sebelumnya bahwa ranah afektif merupakan hasil dari penanaman nilai - nilai dari guru. Sehingga peran dan karakteristik guru yang lebih dominan dalam mempengaruhi hasil penilaian siswa ranah afektif ini. Oleh karena itu guru tidak sekedar "pengajar", tetapi betulbetul sebagai pendidik yang akan memindahkan nilai-nilai itu kepada siswa. Adanya landasan-landasan nilai itu, siswa akan tumbuh kesadaran dan kemauannya untuk mempraktekkan segala sesuatu yang dipelajarinya.

Hasil analisa data berdasarkan rumusan masalah yang ketiga yaitu tidak terdapat perbedaan antara penggunaan model pembelajaran Konvensional dan model pembelajaran Project Based Learning terhadap hasil belajar Gambar Konstruksi Bangunan siswa kelas XI TGB A SMK Negeri 2 Surakarta tahun ajaran 2016/2017 pada aspek penilitian ranah psikomotorik. Hasil ini dapat memperkuat teori sebelumnya bahwa ranah psikomotorik merupakan hasil dari kejelian dan keefektifan guru dalam memilih dan menerapkan model pembelajaran yang tepat dan sesuai karakteristik siswa sehingga dapat mengasah keterampilan siswa serta guru dapat menanamkan konsep dan perumusan konsep kepada siswa.

Dari data di atas dapat disimpulkan bahwa ada perbedaan hasil belajar antara penggunaan model 
pembelajaran konvensional dan model pembelajaran Project Based Learning khususnya di aspek penilaian kognitif yang cenderung meningkat (nilai $\mathrm{Z}$ hitung sebesar -4.657 dengan nilai probabilitas sebesar 0.000), walaupun di aspek penilaian afektif (nilai $\mathrm{Z}$ hitung sebesar -1.224 dengan nilai probabilitas sebesar 0.221) dan psikomotorik (nilai Z hitung sebesar 0.679 dengan nilai probabilitas sebesar 0.497) relatif sama di kedua model pembelajaran pada mata pelajaran Gambar Konstruksi Bangunan di kelas XI TGB A SMK Negeri 2 Surakarta.

\section{SIMPULAN DAN SARAN}

Berdasarkan hasil penelitian yang telah dilakukan maka dapat diperoleh kesimpulan sebagai berikut :

1. Ada perbedaan penilaian kognitif pada model konvensional dibandingkan dengan model Project Based Learning. Yaitu model Project Based Learning lebih baik dibandingkan dengan model konvensional.

2. Tidak ada perbedaan penilaian afektif pada model konvensional dibandingkan dengan model Project Based Learning.
3. Tidak ada perbedaan penilaian psikomotorik pada model konvensional dibandingkan dengan model Project Based Learning.

Akan tetapi dikarenakan pada tahap analisa data didapat bahwa data tidak berdistribusi normal pada ketiga aspek penilaian, hasil dari penelitian ini hanya dapat berlaku pada mata pelajaran Gambar Konstruksi Bangunan Kelas XI TGB A SMK N 2 Surakarta Tahun Ajaran 2016/2017.

Berdasarkan hasil penelitian yang telah dilakukan, terdapat beberapa saran sebagai berikut:

1. Seorang guru hendaknya memiliki kompetensi untuk dapat membimbing diskusi. Khusus dalam model pembelajaran Project Based Learning, peran guru sangat dibutuhkan untuk dapat membimbing masingmasing tim menjadi kelompok yang aktif dan saling bekerjasama.

2. Semua siswa harus berpartisipasi dalam memecahkan masalah, tidak hanya siswa yang aktif saja yang menyelesaikan masalah. Karena dalam model pembelajaran Project Based 
Learning siswa dituntut untuk berperan aktif dalam proses pembelajaran.

3. Dengan adanya keterbatasan waktu pada penelitian ini, maka hendaknya dilakukan penelitian lanjutan menggunakan model pembelajaran Project Based Learning.

\section{DAFTAR PUSTAKA}

Winkel, W.S, (1991). Bimbingan dan Konseling di Sekolah Menengah. Jakarta : PT. Grasindo.

Wena, Made. (2011). Strategi Pembelajaran Inovatif Kontemporer. Jakarta : Bumi Aksara.

Hamalik, Oemar. (2003). Perencanaan Pengajaran Berdasarkan Pendekatan Sistem. Jakarta: Bumi Aksara.

Rusyan, T., Kusdinar, A., \& Arifin, Z. (1989). Pendekatan Dalam Proses Belajar Mengajar. Bandung: Remadja Karya.

Sani, Ridwan Abdullah. (2013). Inovasi Pembelajaran. Jakarta : Bumi Aksara.

Djamarah, Syaiful Bahri. (1996). Strategi Belajar Mengajar. Jakarta : PT Rineka Cipta.
Warsono \& Hariyanto. (2012). Pembelajaran Aktif Teori dan Asesmen. Bandung : PT. Remaja Rosdakarya.

Sopaah, D. (2000). Pengaruh Model Pembelajaran dan Motivasi Berprestasi terhadap Hasil Belajar. Jurnal Pendidikan dan Kebudayaan N0. 02. Tahun ke-5. Maret 2000. 